of students. The Minister of Education and the local education authorities could also assist, and he recognized the importance of developing technical education prior to higher technological education.

\section{Biology as a Career}

A Most useful booklet to all those contemplating a career in biology has been produced by the Institute of Biology. Besides assessing the qualities desirable in a biologist, the booklet contains useful information about the training required for various posts. The most valuable feature of the booklet, however, is the section describing opportunities open to professional biologists in schools, universities and other educational institutions, medical research, agriculture and horticulture, hydrobiology and fisheries, forestry, the Nature Conservancy, the Scientific Civil Service and industry; careers in the British Commonwealth and the Colonies are included. The present and future supply and demand for biologists are also examined and show that, although it is becoming increasingly difficult for less well-qualified biologists to find posts suitable to their qualifications, there is an acute shortage of persons to fill the more responsible positions. Details are provided of the rates of pay of biologists in schools and technical colleges, the universities, the Scientific Civil Service, the Colonial Research Service and industry.

\section{Elementary Meteorology for Young People}

THE most recent of a series of popular lectures promoted by the Royal Meteorological Society was given at the Royal Institution by Mr. J. S. Sawyer on December 2 to an audience consisting almost entirely of pupils from forty-seven London secondary schools. Mr. Sawyer gave a well-illustrated lecture on weather forecasting, in which he traced the development of modern techniques from primitive weather lore to the use of radiosonde upper-air soundings over land and sea. $\mathrm{He}$ described the intricate communication system necessary for a modern forecasting unit and showed in remarkably clear terms how new methods of upper-air analysis are opening the way to longer-range weather forecasting. A brief glimpse into the future indicated that electronic computors would help to deal with the mass of data in the short time available to those preparing a weather forecast. At the end of the lecture, the pupils put questions which were most intelligent and clear, and must have been very satisfying to the teachers present. In view of its popularity, the lecture will be given again on February 4 at 5.30 p.m. in the L.C.C. Lecture Rooms, County Hall, Westminster, London.

\section{Gynospore or Megaspore ?}

WHEN the terms 'megaspore' and 'microspore' are used in relation to the life-cycle of seed plants, most botanists would understand that a typical heterosporous ancestry for seed plants was implied. But does this terminology faithfully represent the facts? In a recent study, J. Doyle ("Gynospore or Megaspore-a Restatement", Ann. Bot., N.S., 17, 67,466 ; 1953) points out that, in measurements of spore size in gymnosperms, the two spore types are found to be at least sub-equal, and that in conifers the pollen or microspore may actually be larger than the megaspore. Sequoia sempervirens is cited as an example of a living species which shows "a direct, transition to the seed condition from what is essentially a homosporous condition". Since, in the author's view, seed origin from homosporous sources cannot be ruled out on the existing evidence, the terms 'gynospore' and 'androspore' may be preferable to those now in general use.

\section{Carbon Dioxide Fixation by Roots}

MANY non-green plant and animal tissues are able to assimilate carbon dioxide. Using carbon-14 dioxide and radiochromatography, L. W. Poel $(J$. Exp. Bot., 4, 11, 155 ; 1953) has investigated the fixation of carbon dioxide by excised barley roots, the non-volatile ethanol-soluble products of fixation being determined. The main radioactive compounds separated were malic, citric (or iso-citric), aspartic, and glutamic acids, and asparagine and glutamine. Less activity was present in serine, tyrosine, $\alpha$-ketoglutaric acid and alanine, and in a number of unidentified compounds. Anaerobic conditions inhibited the uptake of carbon-14 dioxide. The results obtained lead to the conclusion that carbon-14 is probably transformed through the reactions of the tricarboxylic acid cycle.

\section{Gifts of Rock Paintings to the National Museum of Wales}

AN interesting and munificent gift to the National Museum of Wales of forty-five drawings made in quarries and sheds where quarry products are prepared for the market is described by Dr. F. J. North in the November issue of the Museums Journal. The drawings were given by an artist, Miss M. E. Thompson, and constitute an interesting record of contemporary conditions in some of the slate and stone quarries of North Wales and in the Portland quarries in Dorset. Miss Thompson has been outstandingly successful in reproducing the atmosphere of quarries, and her drawings are works of art in addition to being realistic representations of the rocks. She has been equally successful in gaining the confidence of the quarrymen and thus was able to show the work in the mills and even studies of the men themselves. The drawings will do much to illustrate rocks and scenery, and help the public to an appreciation of the beautiful in Nature.

\section{Canadian Journal of Microbiology : Forthcoming Publication}

THE National Research Council of Canada proposes to start a new publication, the Canadian Journal of Microbiology, commencing in August, with subsequent numbers every two months. Dr. R. G. E. Murray, of the Department of Bacteriology, Univer. sity of Western Ontario, has been appointed editor. The Journal will consider for publication scientific papers describing original research in all phases of microbiology, regardless of country of origin ; papers will be published in either English or French. Reviewss will not be accepted. For publication in the first issue, manuscripts should be submitted by April 1, and in this connexion the general instructions to authors given in recent issues of the Canadian Journal of Botany should be followed. The subscription rate for the new journal is 3 dollars a volume. Inquiries should be sent to the Accounts Officer, National Research Council, Sussex Street, Ottawa 2.

\section{Methods of Recording Sound}

AN international meeting on "Methods of Sound Recording and their Applications in Different Fields" will be held in Paris during April 5-10, 1954. The 